\title{
The peripheral perfusion index and transcutaneous oxygen challenge test are predictive of mortality in septic patients after resuscitation
}

\author{
Huai-wu He, Da-wei Liu*, Yun Long and Xiao-ting Wang
}

\begin{abstract}
Introduction: The peripheral perfusion index (PI) is a noninvasive numerical value of peripheral perfusion, and the transcutaneous oxygen challenge test (OCT) is defined as the degree of transcutaneous partial pressure of oxygen $\left(\mathrm{PtcO}_{2}\right)$ response to $1.0 \mathrm{FiO}_{2}$. The value of noninvasive monitoring peripheral perfusion to predict outcome remains to be established in septic patients after resuscitation. Moreover, the prognostic value of PI has not been investigated in septic patients.
\end{abstract}

Methods: Forty-six septic patients, who were receiving PiCCO-Plus cardiac output monitoring, were included in the study group. Twenty stable postoperative patients were studied as a control group. All the patients inspired 1.0 of $\mathrm{FiO}_{2}$ for 10 minutes during the OCT. Global hemodynamic variables, traditional metabolic variables, $\mathrm{PI}$ and OCT related-variables were measured simultaneously at 24 hours after PiCCO catheter insertion. We obtained the 10 min-OCT ((PtcO ${ }_{2}$ after 10 minutes on inspired 1.0 oxygen) - (baseline $\left.\left.\mathrm{PtcO}_{2}\right)\right)$, and the oxygen challenge index ((10 min-OCT)/( $\mathrm{PaO}_{2}$ on inspired 1.0 oxygen - baseline $\left.\left.\mathrm{PaO}_{2}\right)\right)$ during the OCT.

Results: The PI was significantly correlated with baseline $\mathrm{PtcO}_{2}, 10 \mathrm{~min}-\mathrm{OCT}$ and oxygen challenge index (OCl) in all the patients. The control group had a higher baseline $\mathrm{PtcO}_{2}, 10$ min-OCT and PI than the septic shock group. In the sepsis group, the macro hemodynamic parameters and $\mathrm{ScvO}_{2}$ showed no differences between survivors and nonsurvivors. The nonsurvivors had a significantly lower PI, 10min-OCT and $\mathrm{OCl}$, and higher arterial lactate level. The PI, 10min-OCT and $\mathrm{OCI}$ predicted the ICU mortality with an accuracy that was similar to arterial lactate level. A PI $<0.2$ and a $10 \mathrm{~min}-\mathrm{OCT}<66 \mathrm{mmHg}$ were related to poor outcome after resuscitation.

Conclusions: The PI and OCT are predictive of mortality for septic patients after resuscitation. Further investigations are required to determine whether the correction of an impaired level of peripheral perfusion may improve the outcome of septic shock patients.

Keywords: Peripheral perfusion index (PI), transcutaneous oxygen/carbon dioxide tensions $\left(\mathrm{PtcO}_{2} / \mathrm{PtcCO}_{2}\right)$, oxygen challenge test $(\mathrm{OCT})$, septic shock, prognosis

\section{Introduction}

Blood flow is diverted from the peripheral tissue to vital organs during circulation shock. It is assumed that peripheral tissue is the first tissue bed to sacrifice in shock and the last to be reperfused in resuscitation [1,2]. Tissue perfusion is commonly evaluated indirectly by subjective symptoms and imprecise signs, but they are not direct

\footnotetext{
*Correspondence: dwliu98@yahoo.com

Department of Critical Care Medicine, Peking Union Medical College Hospital, Peking Union Medical College, Chinese Academy of Medical Science, 1 Shuaifuyuan, Dongcheng District, Beijing, 100730,China
}

quantitative measures of peripheral tissue perfusion. With the development of new techniques, quantitatively assessment of peripheral tissue perfusion has become popular in clinical practice. The peripheral perfusion index (PI) is derived from the photoelectric plesthysmographic signal of pulse oximetry and has been shown to reflect changes in peripheral perfusion [3,4]. A PI value of 1.4 indicates the presence of poor peripheral perfusion in critically ill patients [3]. Transcutaneous oxygen/ carbon dioxide tensions $\left(\mathrm{PtcO}_{2} / \mathrm{PtcCO}_{2}\right)$ monitoring can provide continuous displays of data, and have been used

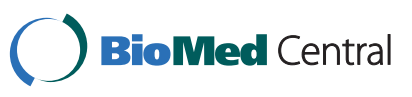


in infants and premature neonates as a surrogate measure of arterial blood gases [5]. Because thicker epidermal layers cause more discrepancy between $\mathrm{PtcO}_{2}$ and arterial pressure of oxygen $\left(\mathrm{PaO}_{2}\right), \mathrm{PtcO}_{2}$ and $\mathrm{PtcCO}_{2}$ have been used to represent tissue oxygenation and perfusion in critically ill adult patients [6-8]. In addition, the oxygen challenge test (OCT) is another new method to reflect cellular $\mathrm{O}_{2}$ deficit. Recent reports using the noninvasive $\mathrm{PtcO}_{2}$ have observed a relationship between low oxygen challenge test values to mortality and new organ failure $[9,10]$.

However, septic shock, in contrast to other forms of shock associated with peripheral vasodilation, is known as 'warm shock'. During septic shock resuscitation, perfusion assessment is difficult and usually a complex determination. The value of peripheral tissue perfusion is controversial in systemic sepsis [11]. To the best of our knowledge, no one has quantified PI to outcome in patients with septic shock. The noninvasive peripheral perfusion potential value to predict outcome remains to be established in septic patients. This study was conducted as a prospective evaluation of the predictive value of the noninvasive peripheral perfusion indicators, traditional metabolic variables, and global hemodynamic parameters in septic patients after resuscitation. This could provide valuable insights about perfusion monitoring in septic patients and help to delineate the potential role and limitations of noninvasive peripheral perfusion as a target for resuscitation.

This study has been partially presented in abstract form [12].

\section{Patients and methods}

The Institutional Research and Ethics Committee of the Peking Union Medical College Hospital approved this study for human subjects. Informed consent was obtained from all patients or next-of-kin before data were included into the study.

When the research team was available, all adult patients within $48 \mathrm{~h}$ after the onset of severe sepsis or septic shock sequentially admitted to the Department of Critical Care Medicine of Peking Union Medical College Hospital, who required $\mathrm{PiCCO}-\mathrm{Plus}$ cardiac output monitoring and mechanical ventilation for resuscitation, were eligible for the study. The attending intensivists decided PiCCO catheter placement according the severity of the patient's condition after the early hemodynamic support. The local reference standard of PiCCO catheter insert is: (1) tissue perfusion or organ function has not improved after early goal-directed therapy [13]; (2) according to the patient's clinical condition, it is difficult for the attending doctor to make a clinical decision of infusion fluid or pressor. Patients excluded from the study were as follows: fraction of inspired oxygen concentration $\left(\mathrm{FiO}_{2}\right)>80 \%$; were pregnant; aged $<18$ years; were not expected to live; were brain dead; due to the decision to withhold or withdraw treatments. Septic shock was defined as severe sepsis with sepsis-induced hypotension persisting, despite adequate fluid resuscitation, and requiring the administration of vasopressors [14].

Twenty stable patients during the first $24 \mathrm{~h}$ of the Department of Critical Care Medicine admission who were ventilated and sedated, without infection, and admitted for postoperative monitoring were measured and considered to be the control group.

\section{Patient management}

All the patients needed mechanical ventilation and sedatives. All septic shock patients received broad-spectrum antibiotic coverage. The local hemodynamic support algorithm of septic shock patients: the early goal-directed therapy was as follows: central venous pressure was 8 to $12 \mathrm{mmHg}$; mean arterial pressure was above $65 \mathrm{mmHg}$; urine output was above $0.5 \mathrm{ml} / \mathrm{kg}$ of body weight (except in the patients with acute renal failure), and the central venous oxygen saturation $\left(\mathrm{ScvO}_{2}\right)$ was at $70 \%$ or more [13]. The advanced goal of hemodynamic support (after PiCCO catheter placement) was as follows: fluid loading was guided according to pulse pressure variation in ventilated patients (pulse pressure variations below 13\% or lack of response to passive leg raising or no respiratory variations of the inferior vena cava diameter ( $\mathrm{Cx}$ Cart; Phillips Ultrasound, Bothell, WA, USA)); systemic vascular resistance index $>1000 \mathrm{dyne} / \mathrm{sec} / \mathrm{cm}^{5}$; after the macro hemodynamic variables were optimized, if the lactate was not decreasing, sources for the elevation of lactate were sought, and/or maneuvers to lower oxygen consumption were instituted (fever control, increase in sedation/pain medication). The intensivists were blinded for the results of the peripheral perfusion variables.

\section{Measurements}

Information collected at enrollment included demographic characteristics such as age; sex; Acute Physiology and Chronic Health Evaluation II score (APACHE II) [15]; Sequential Organ Failure Assessment (SOFA) score [16]; and primary site and type of infection. The global hemodynamic, traditional metabolic, and PI and OCT variables were measured simultaneously at $24 \mathrm{~h}$ after PiCCO catheter insertion.

Simultaneous basic blood gases from the arterial, central venous catheters were obtained (the placement of a central venous catheter in the superior vena cava was confirmed by chest radiography). Blood gas samples were taken anerobically in $3 \mathrm{ml}$ heparinized syringes (PL67BP; BD Diagnostics, Plymouth, UK) and analyzed on blood gas bedside machines (GEM Premier 3000, model 5700; Lexington, MA, USA) or (ABL90: Radiometer, 
Copenhagen, Denmark). The thermodilution cardiac output was measured by injecting $15 \mathrm{ml}$ of $0.9 \%$ saline at $0^{\circ} \mathrm{C}$ for the PiCCO-Plus (the PiCCO system: Pulsion Medical System, Munich, Germany). Three cardiac outputs, which were within $10 \%$ of each other, were obtained and averaged. These global hemodynamic variables were recorded simultaneously.

Transcutaneous sensors (TCM4 Transcutaneous Oxygen/Carbon Dioxide Monitoring System; Radiometer, Copenhagen, Denmark) having previous validation studies were calibrated to known oxygen and carbon dioxide levels according to the manufacturer's guidelines. The sensors were attached to the patients' upper torso below the clavicle in nonbony areas, and skin was prepared with alcohol and shaved when necessary. Areas of injury such as hematomas were avoided. With a total of 15 min equilibration time, heating of the probe to $44^{\circ} \mathrm{C}$ required $5 \mathrm{~min}$. Baseline $\mathrm{PtcO}_{2}$ and $\mathrm{PtcCO}_{2}$ were recorded. The OCTs were performed $\left(\mathrm{FiO}_{2}\right.$ was increased to 1.0 for $\left.10 \mathrm{~min}\right)$, and the new $\mathrm{PtcO}_{2}$ value was recorded every $1 \mathrm{~min}$. The values for $\mathrm{PaO}_{2}$ were examined on inspired of $1.0 \mathrm{FiO}_{2}$. PI and pulse oxygen saturation percentage $\left(\mathrm{SpO}_{2}\right)$ were measured in the index finger by using the IntelliVue MP70 monitor (Philips Medical Systems, Boblingen, Germany). The MP70 system calculates the PI as the ratio between the pulsatile component and the nonpulsatile component of the light reaching the light-sensitive cell of the pulse oximetry probe. The ambient temperature of the room was kept constant at approximately 23 to $25^{\circ} \mathrm{C}$ (climate controlled) during all phases of testing.

\section{Study definitions}

The $\mathrm{PtcO}_{2}$ index is baseline $\mathrm{PtcO}_{2}$ /baseline $\mathrm{PaO}_{2}$; $10 \mathrm{~min}-\mathrm{OCT}$ is $\left(\mathrm{PtcO}_{2}\right.$ after 10 minutes on inspired 1.0 oxygen) - (baseline $\mathrm{PtcO}_{2}$ ); the OCI is (10min-OCT)/ ( $\left(\mathrm{PaO}_{2}\right.$ on inspired 1.0 oxygen) - (baseline $\left.\left.\mathrm{PaO}_{2}\right)\right)$; survival is leaving the ICU alive for that admission.

\section{Statistical analysis}

A descriptive analysis was performed. All data were expressed as mean \pm standard deviation, unless otherwise specified. A Mann-Whitney test was used to compare groups on continuous variables, and chi-square and Fisher's exact tests were used to compare categorical variables. Comparisons of two continuous variables were performed using a linear regression. Discrimination of values was assessed with the receiver operating characteristic analysis. All comparisons were two-tailed, and $P<0.05$ was required to exclude the null hypothesis. The areas under the ROC curves were compared using a Hanley-McNeil test [17]. The statistical analysis was performed by using the software package SPSS version 13.0 (SPSS Inc. Chicago, IL, USA), and MedCalc 11.4.3.0 software (MedCalc, Mariakerke, Belgium).

\section{Results}

From July 2009 to May 2012, a total of 66 patients were enrolled. Fifty-five septic shock patients were screened for the study, and nine septic shock patients were not included in the analysis because of the failure of the correction of $\mathrm{ScvO}_{2}\left(\mathrm{ScvO}_{2}<60 \%\right)$. Twenty-six of the 46 septic shock patients were also engaged in a previous reported study [18]. The median time between the start of the PiCCO catheter insertion and admission to the ICU was $16 \mathrm{~h}$ in the study group. The ICU mortality in the 46 septic shock patients was $43 \%$ (20/46). In this population, there were no differences in the using of norepinephrine (NE), the APACHE and SOFA score and white blood cell (WBC) count between the survivors and the nonsurvivors. The characteristics of the primary infection sites were as follows: 24/46 (52\%) cases of lung; 10/46 (22\%) cases of abdomen; $1 / 46$ (2\%) cases of urinary tract; $2 / 46(4 \%)$ cases of soft tissue; $1 / 46$ (2\%) cases of bloodstream; $8 / 46(17 \%)$ cases of an unknown source. Characteristics of the septic shock patients are shown in Table 1. The control group included 20 hemodynamically stable patients without sepsis admitted for postoperative monitoring. The characteristics of surgery sites were as follows: 16/20 (80\%) cases of abdomen, 4/20 (20\%) cases of other sites. None of these patients was treated with pressor agents. Demographics and clinical characteristics of the study groups and the control groups are shown in Table 2; the mean arterial pressure (MAP) had been corrected in all the septic shock patients at the measurement stage.

\section{Global, metabolic, and peripheral perfusion variables in different groups}

There were no differences in $\mathrm{SpO}_{2}, \mathrm{PtcCO}_{2}$, and arterial lactate level between the control patients and the septic patients (Table 2). The control group had a higher baseline $\mathrm{PaO}_{2}$, baseline $\mathrm{PtcO}_{2}, \mathrm{PaO}_{2}$ (on $\mathrm{FiO}_{2}$ 1.0), MAP, 10 min-OCT and PI than the septic group (Table 3 ). There was no difference in $\mathrm{PtcO}_{2}$ index and OCI between the two groups.

Table 1 Characteristics of the septic patients $(n=46)$.

\begin{tabular}{llll}
\hline Variables & $\begin{array}{l}\text { Survivor } \\
\boldsymbol{n}=\mathbf{2 6}\end{array}$ & $\begin{array}{l}\text { Nonsurvivor } \\
\boldsymbol{n}=\mathbf{2 0}\end{array}$ & $\boldsymbol{P}$ value \\
\hline Age (years) & $58 \pm 16$ & $67 \pm 16$ & 0.080 \\
Sex (female/male) & $8: 18$ & $8: 12$ & 0.515 \\
APACHE II score & $18 \pm 6$ & $20 \pm 6$ & 0.069 \\
SOFA score & $9 \pm 2$ & $10 \pm 2$ & 0.056 \\
Ramsay score & $5 \pm 0.8$ & $5.5 \pm 0.7$ & 0.583 \\
NE & $0.59 \pm 0.67$ & $0.74 \pm 0.62$ & 0.235 \\
WBC & $12.7 \pm 7.8$ & $9.1 \pm 5.9$ & 0.126 \\
\hline
\end{tabular}

${ }^{a} P<0.05$ for survivor group vs. nonsurvivor group. APACHE, Acute Physiology and Chronic Health Evaluation; SOFA, Sequential Organ Failure Assessment score; NE, norepinephrine $(\mu \mathrm{g} / \mathrm{kg} / \mathrm{min})$; WBC, white blood cell count (X 10^9/L). 
Table 2 Comparison of the septic group and the control group.

\begin{tabular}{llll}
\hline Variables & $\begin{array}{l}\text { Control group } \\
\boldsymbol{n}=\mathbf{2 0}\end{array}$ & $\begin{array}{l}\text { Septic group } \\
\boldsymbol{n}=\mathbf{4 6}\end{array}$ & $\boldsymbol{P}$ value \\
\hline Age (years) & $59 \pm 10$ & $62 \pm 16$ & 0.442 \\
Sex (female/male) & $9: 11$ & $16: 30$ & 0.432 \\
APACHE II score & $12 \pm 4$ & $19 \pm 6$ & $0.000^{\mathrm{a}}$ \\
SOFA score & $2 \pm 2$ & $9 \pm 2$ & $0.000^{\mathrm{a}}$ \\
Ramsay score & $5.1 \pm 0.3$ & $5 \pm 1$ & $0.008^{\mathrm{a}}$ \\
$\mathrm{MAP}$ & $93 \pm 9$ & $87 \pm 12$ & $0.024^{\mathrm{a}}$ \\
$\mathrm{SpO}_{2}$ (\%) & $100 \pm 1$ & $99 \pm 2$ & 0.193 \\
Lactate (mmol/L) $^{3}$ & $3.2 \pm 2.2$ & $3.8 \pm 3.9$ & 0.950
\end{tabular}

${ }^{\mathrm{a}} P<0.05$ for control group vs. septic group. APACHE, Acute Physiology and Chronic Health Evaluation; SOFA, Sequential Organ Failure Assessment score; $\mathrm{MAP}$, mean arterial pressure $(\mathrm{mmHg}) ; \mathrm{SpO}_{2}$, arterial oxygen saturation measured by pulse oximetry.

Global, metabolic and peripheral perfusion variables after resuscitation of the septic patients according to survival are shown in Table 3 and Table 4. In this study group, the macro hemodynamic-related parameters, baseline $\mathrm{PtcO}_{2}$, baseline $\mathrm{PtcCO}_{2}, \mathrm{PaO}_{2}$ (on $\mathrm{FiO}_{2}$ 1.0), $\mathrm{PtcO}_{2}$ index and $\mathrm{ScvO}_{2}$ showed no differences between survivors and nonsurvivors. Statistically significant variables between the survivors and the nonsurvivors included arterial lactate level $(2.3 \pm 2$ vs. $5.6 \pm 4.9 \mathrm{mmol} / \mathrm{l}$, $P<0.0001)$, PI $(1.95 \pm 1.5$ vs. $0.6 \pm 0.86, P<0.0001)$, $10 \mathrm{~min}-\mathrm{OCT}(186 \pm 75$ vs. $93 \pm 103 \mathrm{mmHg}, P=0.001)$ and OCI $(0.79 \pm 0.28$ vs. $0.49 \pm 0.36, P=0.01)$.

There were 26 patients in septic group with $\mathrm{ScvO}_{2}$ $\geq 70 \%$ after resuscitation, and the mortality was 9/26 $(35 \%)$ in this subgroup. Statistically significant variables between the survivors and the nonsurvivors included arterial lactate level $(2.3 \pm 1.5$ vs. $5.0 \pm 5.2 \mathrm{mmol} / \mathrm{l}, P=$ $0.034)$, PI ( $2.2 \pm 1.7$ vs. $0.87 \pm 1.1, P=0.013)$.

In the whole group, the PI was not correlated with the baseline $\mathrm{PtcCO}_{2}, \mathrm{PtcO}_{2}$ index and $\mathrm{ScvO}_{2}$. In contrast, the PI was correlated with baseline $\mathrm{PtcO}_{2}(\mathrm{r}=0.298$,
Table 4 Global and metabolic variables in the septic patients according to their survival

\begin{tabular}{|c|c|c|c|c|}
\hline Variables & $\begin{array}{l}\text { Total } \\
n=46\end{array}$ & $\begin{array}{l}\text { Survivor } \\
n=26\end{array}$ & $\begin{array}{l}\text { Nonsurvivor } \\
n=20\end{array}$ & $P$ value \\
\hline Blood temp $\left({ }^{\circ} \mathrm{C}\right)$ & $38 \pm 1.1$ & $38 \pm 0.9$ & $38.1 \pm 1.4$ & 0.564 \\
\hline PEEP & $7 \pm 3$ & $7 \pm 3$ & $7 \pm 2$ & 0.910 \\
\hline Basic $\mathrm{FiO}_{2}$ & $49 \pm 9$ & $47 \pm 8$ & $51 \pm 9$ & 0.078 \\
\hline MAP & $87 \pm 12$ & $88 \pm 12$ & $85 \pm 12$ & 0.513 \\
\hline CVP & $11 \pm 3$ & $12 \pm 3$ & $11 \pm 4$ & 0.319 \\
\hline $\mathrm{Cl}$ & $3.7 \pm 1$ & $3.9 \pm 0.8$ & $3.6 \pm 1.3$ & 0.111 \\
\hline SVRI & $1705 \pm 559$ & $1676 \pm 474$ & $1742 \pm 664$ & 0.982 \\
\hline GEDVI & $805 \pm 162$ & $744 \pm 125$ & $844 \pm 197$ & 0.341 \\
\hline $\mathrm{ScvO}_{2}(\%)$ & $71 \pm 8$ & $72 \pm 8$ & $69 \pm 8$ & 0.156 \\
\hline $\mathrm{PV}-\mathrm{a} \mathrm{CO}_{2}$ & $6 \pm 3$ & $5 \pm 3$ & $7 \pm 4$ & 0.144 \\
\hline Lactate (mmol/L) & $3.8 \pm 3.9$ & $2.3 \pm 2$ & $5.6 \pm 4.9$ & $0.000^{a}$ \\
\hline
\end{tabular}

${ }^{\mathrm{a}} \mathrm{P}<0.05$ for survivor vs. nonsurvivor. PEEP, positive end-expiratory pressure $\left(\mathrm{cmH}_{2} \mathrm{O}\right) ; \mathrm{FiO}_{2}$, fraction of inspired oxygen concentration; MAP, mean arterial pressure $(\mathrm{mmHg})$; $\mathrm{CVP}$, central venous pressure $(\mathrm{mmHg}) ; \mathrm{Cl}$, cardiac index $\left(\mathrm{L} / \mathrm{min} / \mathrm{m}^{2}\right)$; SVRI, systemic vascular resistance index (dyne $\left./ \mathrm{sec} / \mathrm{cm}^{5}\right)$; GEDVI, global end-diastolic volume index $\left(\mathrm{ml} / \mathrm{m}^{2}\right) ; \mathrm{ScvO}_{2}$, central venous oxygen saturation; $\mathrm{Pv}-\mathrm{a} \mathrm{CO}_{2}$, difference between central venous and arterial $\mathrm{PCO}_{2}(\mathrm{mmHg})$.

$P=0.015), 10 \min -\mathrm{OCT}(\mathrm{r}=0.573, P<0.0001), \mathrm{OCI}$ ( $\mathrm{r}=0.395, P=0.001)$, lactate $(\mathrm{r}=-0.309, P=0.012)$. There is a significantly positive relationship between $\mathrm{PaCO}_{2}$ and $\mathrm{PtcCO}_{2}(\mathrm{r}=0.874, P<0.0001)$.

\section{Metabolic and peripheral perfusion variables as predictors of mortality}

The cutoff value and areas under the receiver operating characteristic (ROC) curves for the related variables used for predicting ICU mortality are shown in Table 5. The cutoff of the PI value was $\leq 0.2$ for predicting ICU mortality, resulting in a sensitivity of $65 \%$ and a specificity of $92.3 \%$. The PI, $10 \mathrm{~min}-\mathrm{OCT}$ and OCI predicted the ICU mortality with an accuracy that was similar to arterial lactate level, and the PI was significantly better than the difference between central venous and arterial

Table 3 Peripheral perfusion related-variables in the different groups

\begin{tabular}{|c|c|c|c|c|}
\hline Variables & $\begin{array}{l}\text { Controls } \\
n=20\end{array}$ & $\begin{array}{l}\text { All sepsis } \\
n=46\end{array}$ & $\begin{array}{l}\text { Survivor sepsis } \\
n=26\end{array}$ & $\begin{array}{l}\text { Nonsurvivor sepsis } \\
n=20\end{array}$ \\
\hline$\overline{\mathrm{Pl}}$ & $2.58 \pm 0.68^{a, c}$ & $1.37 \pm 1.43$ & $1.95 \pm 1.5^{c}$ & $0.6 \pm 0.86$ \\
\hline $\mathrm{PtcO}_{2}$ & $124 \pm 45^{a, b, c}$ & $73 \pm 24$ & $79 \pm 21$ & $66 \pm 26$ \\
\hline $\mathrm{PaO}_{2}$ (on basic $\mathrm{FiO}_{2}$ ) & $179 \pm 70^{a, b, c}$ & $119 \pm 45$ & $125 \pm 51$ & $111 \pm 37$ \\
\hline $\mathrm{PtcO}_{2}$ index & $0.71 \pm 0.29$ & $0.67 \pm 0.22$ & $0.69 \pm 0.21$ & $0.64 \pm 0.24$ \\
\hline $\mathrm{PtcCO}_{2}$ & $36 \pm 7$ & $36 \pm 9$ & $38 \pm 7$ & $34 \pm 12$ \\
\hline $\mathrm{PaCO}_{2}$ & $35 \pm 6$ & $36 \pm 8$ & $37 \pm 6$ & $35 \pm 10$ \\
\hline 10min-OCT & $247 \pm 65^{a, b, c}$ & $145 \pm 99$ & $186 \pm 75^{c}$ & $93 \pm 103$ \\
\hline $\mathrm{PaO}_{2}$ (on $1.0 \mathrm{FiO}_{2}$ ) & $489 \pm 106^{a, b, c}$ & $343 \pm 122$ & $371 \pm 116$ & $307 \pm 123$ \\
\hline $\mathrm{OCl}$ & $0.83 \pm 0.2^{c}$ & $0.66 \pm 0.35$ & $0.79 \pm 0.28^{c}$ & $0.49 \pm 0.36$ \\
\hline
\end{tabular}

${ }^{\mathrm{a}} P<0.05$ for controls vs. all sepsis; ${ }^{\mathrm{b}} P<0.05$ for controls vs. survivor sepsis; ${ }^{\mathrm{c}} P<0.05$ for controls vs. nonsurvivor sepsis. Pl, peripheral perfusion index measured by pulse oximetry; $\mathrm{FiO}_{2}$, fraction of inspired oxygen concentration; $\mathrm{PtcO}_{2}$, transcutaneous partial pressure of oxygen (mmHg); $\mathrm{PaO}$, arterial pressure of oxygen $(\mathrm{mmHg}) ; \mathrm{PtCCO}_{2}$, transcutaneous partial pressure of carbon dioxide $(\mathrm{mmHg}) ; \mathrm{PaCO}_{2}$, arterial pressure of carbon dioxide (mmHg); $10 \mathrm{~min}-\mathrm{OCT}, 10 \mathrm{minute}$ oxygen challenge test value $(\mathrm{mmHg}) ; \mathrm{OCl}$, oxygen challenge index. 
Table 5 Comparison of the areas under the ROC curves for predicting ICU mortality in the septic patients.

\begin{tabular}{llllll}
\hline & ROC area & $95 \% ~ C l$ & Cutoff value & Sensitivity (\%) & Specificity (\%) \\
\hline Lactate & 0.80 & $0.658-0.905$ & 4.2 & 45 & 84.62 \\
$\mathrm{PV}-\mathrm{a} \mathrm{CO}$ & $0.62^{\mathrm{a}}$ & $0.469-0.762$ & 7 & 40 & 88.46 \\
$\mathrm{Pl}$ & 0.84 & $0.698-0.929$ & 0.2 & 65 & 92.3 \\
$\mathrm{ScrO}_{2}$ & $0.62^{\mathrm{a}}$ & $0.468-0.762$ & 0.67 & 55 & 73.08 \\
$\mathrm{PtcO}_{2}$ & $0.66^{\mathrm{b}}$ & $0.508-0.795$ & 61 & 55 & 80.8 \\
$\mathrm{PtcO}_{2}$ index & $0.54^{\mathrm{c}}$ & $0.387-0.688$ & 0.51 & 30 & 76.92 \\
$10 \mathrm{~min}-\mathrm{OCT}$ & 0.81 & $0.662-0.907$ & 66 & 65 & 96.2 \\
$\mathrm{OCl}$ & 0.74 & $0.588-0.857$ & 0.55 & 60 & 88.5 \\
\hline
\end{tabular}

${ }^{\mathrm{a}} \mathrm{P}<0.05$ for comparison of $\mathrm{Pv}-\mathrm{a} \mathrm{CO}_{2}, \mathrm{ScvO}_{2} \mathrm{vs}, \mathrm{Pl} ;{ }^{\mathrm{b}} \mathrm{P}<0.05$ for comparison of $\mathrm{PtcO}_{2}$ vs. $\mathrm{Pl}$, lactate; ${ }^{\mathrm{c}} \mathrm{P}<0.05$ for comparison of $\mathrm{PtcO}{ }_{2}$ index vs. 10 min-OCT, OCl, $\mathrm{PI}$ and lactate. $\mathrm{ROC}$, receiver operating characteristic; $\mathrm{Cl}$ confidence interval; $\mathrm{Pv}$-a $\mathrm{CO}_{2}$, difference between central venous and arterial $\mathrm{PCO}{ }_{2}$ (mmHg); $\mathrm{PI}$, peripheral perfusion index measured by pulse oximetry; $\mathrm{ScvO}_{2}$, central venous oxygen saturation; 10 min-OCT, 10 minute oxygen challenge test value (mmHg); $\mathrm{OCl}$, oxygen challenge index.

$\mathrm{PCO}_{2}\left(\mathrm{P}(\mathrm{v}-\mathrm{a}) \mathrm{CO}_{2}\right)$ and $\mathrm{ScvO}_{2}$. In these $\mathrm{PtcO}_{2}$-related parameters, the $10 \mathrm{~min}-\mathrm{OCT}$ and $\mathrm{OCI}$ were significant predictors of lethal outcome, but not baseline $\mathrm{PtcO}_{2}$ and $\mathrm{PtcO}_{2}$ index. For predicting ICU mortality, a threshold of $10 \mathrm{~min}-\mathrm{OCT}$ at $66 \mathrm{mmHg}$ was associated with a sensitivity of $65 \%$ and a specificity of $96.2 \%$, and a cutoff of OCI at 0.55 was associated with a sensitivity of $60 \%$ and a specificity of $88.5 \%$. The ROC curves of baseline $\mathrm{PtcO}_{2}, \mathrm{PtcO}_{2}$ index, 10min-OCT and OCI are shown in Figure 1, and the ROC curves of PI, lactate, $\mathrm{ScvO}_{2}$ and $\mathrm{Pv}-\mathrm{aCO}{ }_{2}$ are shown in Figure 2.

\section{Discussion}

The main finding of our study was that lower peripheral perfusion and higher metabolic variables are associated with increased ICU mortality in septic patients after resuscitation. The PI, 10min-OCT and OCI predicted the ICU mortality with an accuracy that was similar to arterial lactate level. Thus, peripheral perfusion monitoring appears as a simple but powerful tool to assess global resuscitation status and outcome.

As we know, this is the first study to explore the relationship between PI and ICU mortality in septic patients after resuscitation. We found that the cutoff of the PI value was $\leq 0.2$ for predicting ICU mortality, resulting in a sensitivity of $65 \%$ and a specificity of $92.3 \%$. The PI, which was defined as the ratio of the pulsatile to nonpulsatile component of the pulse oximetry plethysmograph, is used as a simple and accurate indication of changes in digital blood flow. It has been suggested as a reliable and early indicator of regional block success, and known to increase due to the effect of autonomic blockade during spinal anesthesia $[4,19,20]$. Some studies showed that PI could be used too as a predictor of early adverse respiratory neonatal outcome after elective cesarean delivery [21].

The change of the finger PI resulted from the blood volume pulsations, the dispensability of the vascular wall and the intravascular pulse pressure, which can be complicated in critically ill adult patients [22,23]. Therefore, many factors can impact the PI value (temperature, level of consciousness, pain and other stressful stimuli, endogenous catecholamines, vasopressors). All the patients needed mechanical ventilation and sedatives, and there were no difference in temperature, Ramsay score, and the dose of NE between survivors and nonsurvivors in the study group. Therefore, the PI was relatively comparable in this study. Our study found that PI was significantly lower in the patients with septic shock than in the control group. One can argue that the using of NE may have an effect on PI in the septic patients. However, the nonsurvivors also had a significantly lower PI than survivors in the patients with septic shock. The correlation between hyperlactatemia and PI in our patients could be related to the presence of tissue hypoperfusion. We demonstrated that a value of PI below 0.2 was associated with an increased risk of ICU mortality. Recently, van Genderen and colleagues found that persistent peripheral and microcirculatory perfusion alterations after out-of-hospital cardiac arrest are associated with organ failure and death, independent of systemic hemodynamics. They reported the PI value was $0.3 \pm 0.28$ in the nonsurvivor at $24 \mathrm{~h}$ after rewarming, which is similar to our results in the nonsurvivor after resuscitation [24].

The impact of possible therapy aimed at increasing the PI was not explored in current study. There is a need of further investigations to test such hypothesis. In our study, we investigated the relationship between PI and $\mathrm{PtcO}_{2}$-related parameters in critically ill patients. The PI was significantly correlated with baseline $\mathrm{PtcO}_{2}, 10 \mathrm{~min}$ OCT and OCI. We concluded that all these parameters are dependent on peripheral blood flow, and reflect peripheral tissue perfusion.

$\mathrm{PtcO}_{2} / \mathrm{PtcCO}_{2}$ is the direct measurement of the local partial pressure of oxygen/carbon dioxide, achieved by placing a Clark polarographic oxygen/carbon dioxide electrode on the skin surface. When the circulation is normal, the $\mathrm{PtcO}_{2}$ reflects $\mathrm{PaO}_{2}$, but in low flow state, it always 


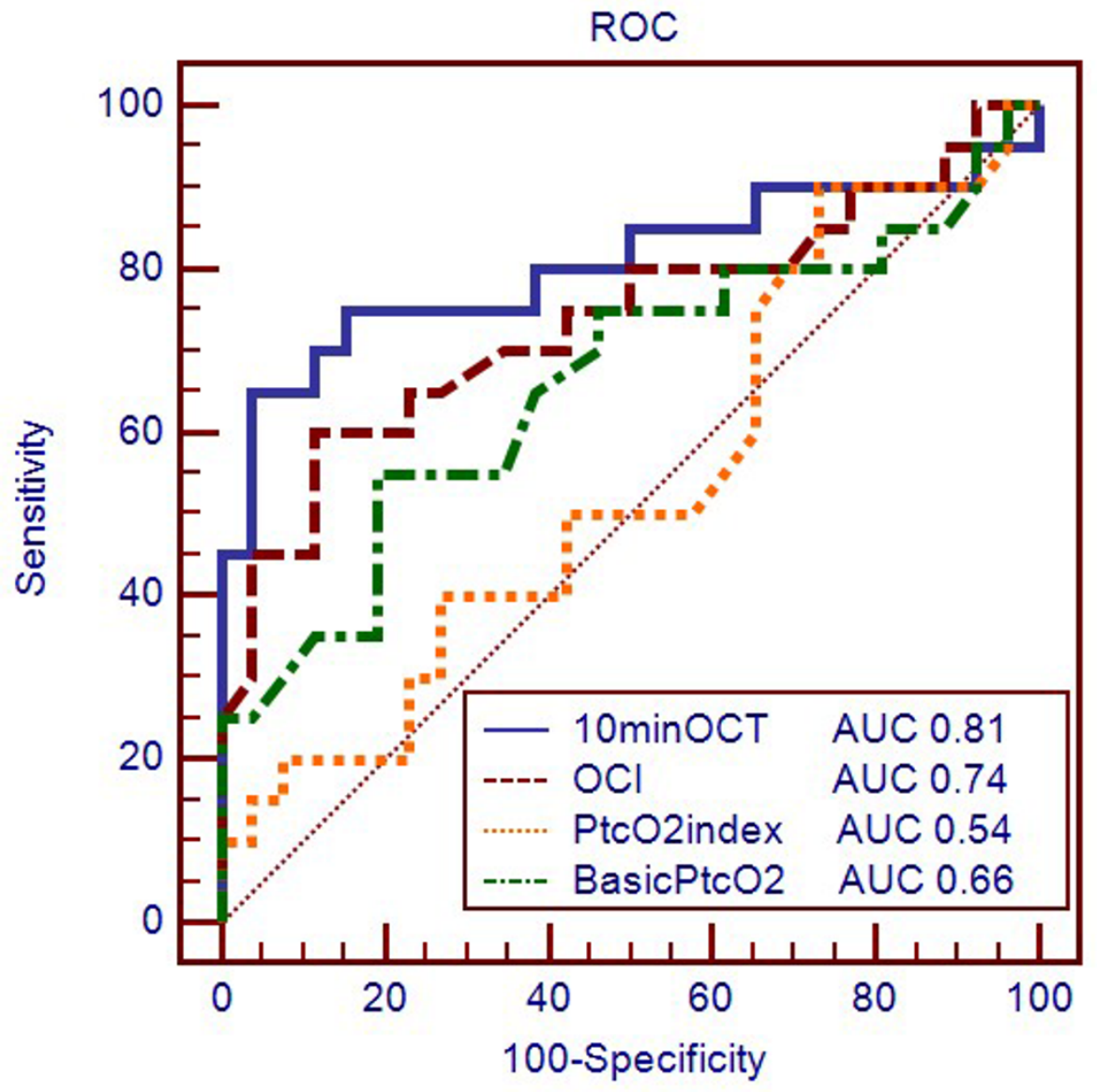

Figure $1 \mathrm{ROC}$ curves comparing the ability of 10 min-OCT, OCl, baseline $\mathrm{PtcO}_{2}$ and $\mathrm{PtcO}_{2}$ index to discriminate ICU mortality. 10 min$\mathrm{OCT}, 10$ minute oxygen challenge test value $(\mathrm{mmHg})$; $\mathrm{OCl}$, oxygen challenge index; $\mathrm{PtcO}_{2}$, transcutaneous partial pressure of oxygen $(\mathrm{mmHg})$; $\mathrm{PtcO}_{2}$ index, transcutaneous partial pressure of oxygen index; AUC, area under the receiver operating characteristic (ROC) curve.

underestimates $\mathrm{PaO}_{2}$. Shoemaker et al. attempted the translation of $\mathrm{PtcO}_{2}$ values to cardiac hemodynamics, when they explored the dependence of $\mathrm{PtcO}_{2}$ on $\mathrm{PaO}_{2}$ using a $\mathrm{PtcO}_{2}$ index $\left(\mathrm{PtcO}_{2} / \mathrm{PaO}_{2}\right)$ to assess the severity of low flow shock [6]. A $\mathrm{PtcO}_{2}$ index below 0.7 has been associated with hemodynamic failure in adult patients $[25,26]$. The $\mathrm{PtcO}_{2}$ index has been used to estimate the adequacy of cardiac output and peripheral blood flow. The OCT is another method to determine the situation of circulation using the noninvasive $\mathrm{PtcO}_{2}$ technique. In nonshock states, $\mathrm{PtcO}_{2}$ correlates with $\mathrm{PaO}_{2}$ to strongly increase response to the $\mathrm{FiO}_{2}$. When peripheral perfusion severely decreases, the $\mathrm{PtcO}_{2}$ values will deviate from their relationship with the arterial tensions and lack of response to a $\mathrm{FiO}_{2}$ of 1.0. In our previous study, we showed that an OCT could improve the diagnostic accuracy of the $\mathrm{PtcO}_{2}$ in estimating the cardiac index $(\mathrm{CI})$ value, and a cutoff $10 \mathrm{~min}$-OCT value of $53 \mathrm{mmHg}$ has a good positive predictive value and positive likelihood ratio for predicting low CI value [18].
We mainly explored the correlation between the outcome and the OCT in this study. We found that the control group had a higher baseline $\mathrm{PaO}_{2}, \mathrm{PaO}_{2}$ (on $\mathrm{FiO}_{2}$ 1.0), 10 min-OCT than the septic shock group. Therefore, we speculated the control group had a better lung function. However, there were no difference of baseline $\mathrm{PaO}_{2}$ and $\mathrm{PaO}_{2}$ (on $\mathrm{FiO}_{2}$ 1.0) between the survivors and nonsurvivors. Hence, $\mathrm{PtcO}_{2}$ showing a poor response of $\mathrm{FiO}_{2} 1.0$ in the nonsurvivor was not due to the lung function, but due to a poor peripheral tissue flow. Moreover, the $10 \mathrm{~min}-\mathrm{OCT}$ and OCI as a predictor of lethal outcome were more sensitive and specific than baseline $\mathrm{PtcO}_{2}$ and $\mathrm{PtcO}_{2}$ index in the patients with septic shock. For predicting ICU mortality, a threshold of $10 \mathrm{~min}$-OCT at $66 \mathrm{mmHg}$ was associated with a sensitivity of $65 \%$ and a specificity of $96.2 \%$, and a cutoff of the OCI at 0.55 was associated with a sensitivity of $60 \%$ and a specificity of $88.5 \%$. In addition, there is another hypothesis for the OCT to determine tissue perfusion. If there is a cellular oxygen deficit, then 


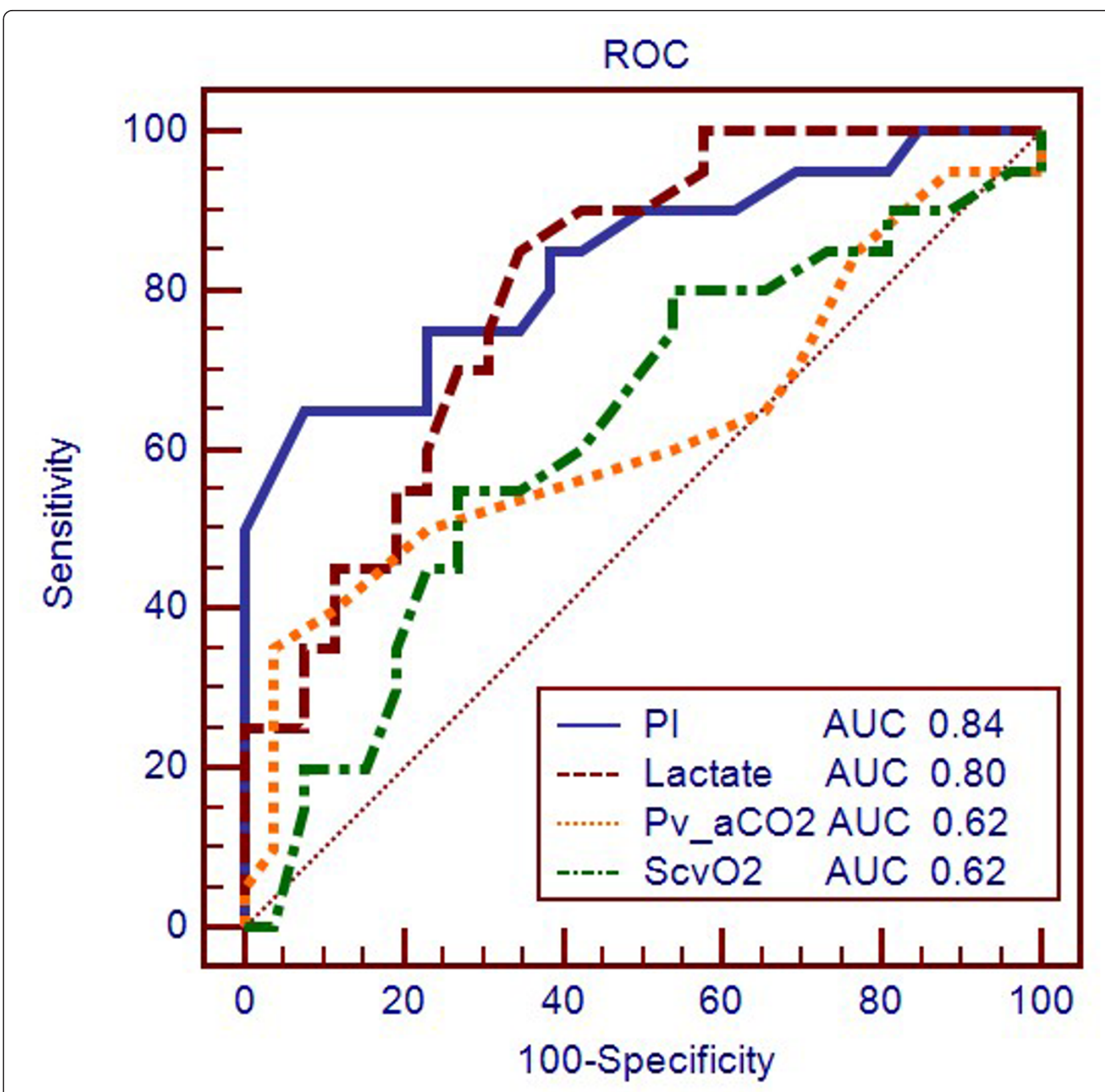

Figure $2 \mathrm{ROC}$ curves comparing the ability of $\mathrm{PI}$, lactate, $\mathrm{Pv}$-a $\mathrm{CO}_{2}$ and $\mathrm{ScvO}_{2}$ to discriminate ICU mortality. $\mathrm{Pl}$, peripheral perfusion index measured by pulse oximetry; $\mathrm{PV}-\mathrm{aCO}$, difference between central venous and arterial $\mathrm{PCO}_{2}(\mathrm{mmHg}) ; \mathrm{ScvO}_{2}$, central venous oxygen saturation; $A \cup C$, area under the receiver operating characteristic (ROC) curve.

the additional dissolved oxygen after the oxygen challenge would be utilized, resulting in a minimum rise in $\mathrm{PtcO}_{2}$. The OCT as a method to assess tissue perfusion mainly described in adult patients by using intramuscular $\mathrm{PO}_{2}$, as in the previous study [27,28]. Yu et al. reported an incremental change of less than $21 \mathrm{mmHg}$ in $\mathrm{PtcO}_{2}$ in response to a $1.0 \mathrm{FiO}_{2}$ has been associated with mortality reports during $5 \mathrm{~min}$-OCT [9]. Our previous study found that there were substantial differences between the oxygen challenge at 5 minutes and $10 \mathrm{~min}$ utes, with the $\mathrm{PtcO}_{2}$ value at 10 minutes always being higher than at 5 minutes [18]. The ideal response time of $\mathrm{PtcO}_{2}$ on OCT is not well established in critically ill adult patients. Shah et al. suggested that the ideal time for the OCT is at least 10 minutes in the evaluation of patients with hypoxic wounds [29]. Further studies are necessary to identify which is the ideal time interval for the OCT. In addition, a multitude of factors can impact 
$\mathrm{PtcO}_{2}$, and the regulation of skin microcirculation during increasing normobaric oxygen is complex [30]. Therefore, the application of an OCT to assess cellular oxygen deficit still needs further investigation.

There are several advantages of the PI and OCT in comparison with the current global endpoints of resuscitation: (1) the peripheral perfusion indicators may provide a specific endpoint of resuscitation rather than the average survival values of $\mathrm{ScvO}_{2}$; $(2)$ the peripheral perfusion monitors may provide information on internal organ perfusion with the assumption that the peripheral tissue is the last to perfuse during shock resuscitation; (3) the techniques are noninvasive, and the equipment is readily available and inexpensive. Its importance will be affirmed if peripheral perfusion monitoring during shock resuscitation becomes routine, and if the critical values defined in this paper are validated by further study.

In recent years, tissue oxygen saturation $\left(\mathrm{StO}_{2}\right)$ has been applied to estimate regional perfusion by nearinfrared spectroscopy (NIRS), and the changes of $\mathrm{StO}_{2}$ during a vascular occlusion test (VOT) have been used as a marker of microvascular reactivity [31-35]. Lima showed that PI correlates with $\mathrm{StO}_{2}$, and that peripheral circulation influences $\mathrm{StO}_{2}$ resting values and the $\mathrm{StO}_{2}$ reoxygenation rate [36,37]. In addition, the changes of $\mathrm{PI}$ and $\mathrm{PtcO}_{2}$ could be used to evaluate microvascular reactive hyperemia as during a VOT $[38,39]$. Therefore, we infer that all three $\left(\mathrm{StO}_{2}, \mathrm{PI}\right.$, and $\left.\mathrm{PtcO}_{2}\right)$ indicators are used to assess regional perfusion and reactive hyperemia with close values.

\section{Limitations}

Several limitations should be acknowledged. First, the study period may be considered not long enough to evaluate other relevant clinical outcomes and the selected time points are relatively arbitrary. A small number of subjects at a single time point is an important issue and our findings should be confirmed in a larger multicenter study before being translated into regular clinical practice. Second, one can argue that the assessment of these objective parameters requires stability of a number of factors that might affect tissue perfusion and oxygenation. To reduce those uncertainty factors, we strictly stabilized the related parameters (ambient temperature, level of consciousness, hemodynamic status). Third was our failure to directly determine skin microcirculation, local blood flow and subjective peripheral tissue perfusion indicators in this study. Fourth, one can argue that this chest skin circulation is not representative of other site circulations. Recently, some studies have been done to explore the value of evaluating peripheral tissue perfusion of other sites in septic shock patients, such as thenar, deltoid, masseter, and ear sites [40,41]. Peripheral tissue perfusion monitoring from different parts may have different values. According to previously published studies on critically ill patients [8-10], we chose the chest site as a relatively standard location for $\mathrm{PtcO}_{2}$ monitoring. Moreover, the PI could be considered as a method to assess the finger tip circulation in this study. We found that the two site-related parameters were both predictive for outcome, and there was a significant relationship between chest and finger tip site-related parameters. Further studies should be done to test the clinical worth of $\mathrm{PtcO}_{2}$ in other sites in critically ill patients. Fifth, MAP had been corrected in all the septic shock patients at the measurement stage, but not for $\mathrm{ScvO}_{2}$. It is difficult for an observational study to guarantee the $\mathrm{ScvO}_{2} \geq 70 \%$ in clinical practice after resuscitation. In our study, $57 \%$ of the septic patients' $\mathrm{ScvO}_{2}$ were equal or greater than $70 \%$ after resuscitation. We excluded nine septic patients in the analysis with low $\mathrm{ScvO}_{2}(<60 \%)$ after resuscitation, and these patients had high lactate and poor peripheral perfusion. We acknowledge that the using of $\mathrm{ScvO}_{2}<60 \%$ to reveal the imbalance between oxygen delivery and oxygen consumption is relatively arbitrary. According to early goal-directed therapy, $\mathrm{ScvO}_{2} \geq 70 \%$ is used to reflect the balance between oxygen delivery and oxygen consumption. Therefore, we analyzed a subgroup of septic shock patients with $\mathrm{ScvO}_{2} \geq 70 \%$, and we found these peripheral indicators still work. This revealed that peripheral perfusion parameters may provide a specific endpoint of resuscitation after $\mathrm{ScvO}_{2} \geq 70 \%$.

\section{Conclusions}

The PI and OCT are predictive of mortality for septic patients after resuscitation, comparable to arterial blood lactate. Further investigations are required to determine whether the correction of an impaired peripheral tissue value may improve the outcome of these patients.

\section{Key messages}

- The PI and OCT are predictive of mortality for septic patients after resuscitation, comparable to arterial blood lactate.

- For predicting ICU mortality, the cutoff of the PI value was $\leq 0.2$ resulting in a sensitivity of $65 \%$ and a specificity of $92.3 \%$, and a threshold of $10 \mathrm{~min}-\mathrm{OCT}$ at $66 \mathrm{mmHg}$ was associated with a sensitivity of $65 \%$ and a specificity of $96.2 \%$.

- The peripheral perfusion indicators may provide a specific endpoint of resuscitation.

\section{Abbreviations}

APACHE: Acute Physiology and Chronic Health Evaluation; Cl: cardiac index; CVP: central venous pressure; $\mathrm{FiO}_{2}$. fraction of inspired oxygen concentration; GEDVI: global-heart end-diastolic volume index; ICU: intensive care unit; MAP: mean arterial pressure; NE: norepinephrine; NIRS: near-infrared 
spectroscopy; OCl: oxygen challenge index; OCT: oxygen challenge test; $\mathrm{PaCO}_{2}$ : arterial pressure of carbon dioxide; $\mathrm{PaO}_{2}$ : arterial partial pressure of oxygen; PEEP: positive end-expiratory pressure; Pl: peripheral perfusion index; $\mathrm{PtcCO}_{2}$ : transcutaneous partial pressure of carbon dioxide; $\mathrm{PtcO}_{2}$ : transcutaneous partial pressure of oxygen; $\mathrm{Pv}-\mathrm{aCO}_{2}$ : difference between central venous and arterial $\mathrm{PCO}_{2} ; \mathrm{ROC}$ : receiver operating characteristic; $\mathrm{ScrO}_{2}$ : central venous oxygen saturation; $\mathrm{SpO}_{2}$ : pulse oxygen saturation percentage; SOFA: Sequential Organ Failure Assessment; $\mathrm{StO}_{2}$ : tissue oxygen saturation; SVRI: systemic vascular resistance index; VOT: vascular occlusion test; WBC: white blood cell count; 10min-OCT: 10 minute oxygen challenge test value.

\section{Competing interests}

The authors declare that they have no competing interests.

\section{Authors' contributions}

DL conceived and designed the study, interpreted data and helped draft the manuscript. HWH participated in the study conception and design, recruited patients, collected data, performed the statistical analysis, interpreted the data and drafted the manuscript. YL and XTW participated in patient recruitment, data collection, technical support and contributed to the critical review of the manuscript. All of the authors read and approved the final manuscript.

\section{Acknowledgements}

The authors thank all nurses, residents, and other personnel of the participating department of Critical Care Medicine for their generous cooperation with special thanks to Jing Zhang for her contribution to the review of the manuscript.

Received: 31 January 2013 Revised: 6 April 2013

Accepted: 20 June 2013 Published: 20 June 2013

\section{References}

1. Chien LC, Lu KJ, Wo CC, Shoemaker WC: Hemodynamic patterns preceding circulatory deterioration and death after trauma. J Trauma 2007, 62:928-932.

2. Poeze M, Solberg BC, Greve JW, Ramsay G: Monitoring global volumerelated hemodynamic or regional variables after initial resuscitation: what is a better predictor of outcome in critically ill septic patients? Crit Care Med 2005, 33:2494-2500.

3. Lima AP, Beelen P, Bakker J: Use of a peripheral perfusion index derived from the pulse oximetry signal as a noninvasive indicator of perfusion. Crit Care Med 2002, 30:1210-1213.

4. Galvin EM, Niehof S, Verbrugge SJ, Maissan I, Jahn A, Klein J, van Bommel J: Peripheral flow index is a reliable and early indicator of regional block success. Anesth Analg 2006, 103:239-243.

5. Monaco F, McQuitty JC: Transcutaneous measurement of carbon dioxide partial pressure in sick neonates. Crit Care Med 1981, 9:756-758.

6. Tremper KK, Shoemaker WC: Transcutaneous oxygen monitoring of critically ill adults, with and without low flow shock. Crit Care Med 1981, 9:706-709.

7. Shoemaker WC, Belzberg H, Wo CC, Milzman DP, Pasquale MD, Baga L, Fuss MA, Fulda GJ, Yarbrough K, Van DeWater JP, Ferraro PJ, Thangathurai D, Roffey P, Velmahos G, Murray JA, Asensio JA, ElTawil K, Dougherty WR, Sullivan MJ, Patil RS, Adibi J, James CB, Demetriades D: Multicenter study of noninvasive monitoring systems as alternatives to invasive monitoring of acutely ill emergency patients. Chest 1998, 114:1643-1652.

8. Tatevossian RG, Wo CC, Velmahos GC, Demetriades D, Shoemaker WC Transcutaneous oxygen and $\mathrm{CO} 2$ as early warning of tissue hypoxia and hemodynamic shock in critically ill emergency patients. Crit Care Med 2000, 28:2248-2253.

9. Yu M, Morita SY, Daniel SR, Chapital A, Waxman K, Severino R: Transcutaneous pressure of oxygen: a non-invasive and early detector of peripheral shock and outcome. Shock 2006, 26:450-456.

10. Yu M, Chapital A, Ho HC, Wang J, Takanishi D jr: A prospective randomized trial comparing oxygen delivery versus transcutaneous pressure of oxygen values as resuscitative goals. Shock 2007, 27:615-622.

11. Sair M, Etherington PJ, Peter Winlove C, Evans TW: Tissue oxygenation and perfusion in patients with systemic sepsis. Crit Care Med 2001, 29:1343-1349.
12. He H, Liu D, Long $Y$, Wang $X T$ : The peripheral perfusion index and transcutaneous oxygen challenge test are predictive of mortality in septic patients after resuscitation [abstract]. Crit Care Med 2012, Suppl 40: S833.

13. Rivers E, Nguyen B, Havstad S, Ressler J, Muzzin A, Knoblich B, Peterson E, Tomlanovich M: Early goal directed therapy in the treatment of severe sepsis and septic shock. New Engl I Med 2001, 345:1368-1377.

14. Levy MM, Fink MP, Marshall JC, Abraham E, Angus D, Cook D, Cohen J, Opal SM, Vincent JL, Ramsay G: 2001 SCCM/ESICM/ACCP/ATS/SIS International Sepsis Definitions Conference. Crit Care Med 2003, 31:1250-1256.

15. Knaus WA, Draper EA, Wagner DP, Zimmerman JE: APACHE II: a severity of disease classification system. Crit Care Med 1985, 13:818-829.

16. Vincent JL, Moreno R, Takala J, Willatts $S$, De Mendonça A, Bruining H, Reinhart CK, Suter PM, Thijs LG: The SOFA (Sepsis-Related Organ Failure Assessment) score to describe organ dysfunction/failure. Intensive Care Med 1996, 22:707-710.

17. Hanley JA, McNeil BJ: The meaning and use of the area under a receiver operating characteristic (ROC) curve. Radiology 1982, 43:29-36.

18. He HW, Liu DW, Long $Y$, Wang XT, Chai WZ, Zhou X: The transcutaneous oxygen challenge test: A noninvasive method for detecting low cardiac output in septic patients. Shock 2012, 37:152-155.

19. Hager H, Church S, Mandadi G, Pulley D, Kurz A: The perfusion index measured by a pulse oximeter indicates pain stimuli in anesthetized volunteers [abstract]. Anesthesiology 2004, 101:A514.

20. Kakazu CZ, Wu T, Chen B-J: Masimo set technology using perfusion index is a sensitive indicator for epidural onset [abstract]. Anesthesiology 2005, 103:A576.

21. De Felice C, Leoni L, Tommasini E, Tonni G, Toti P, Del Vecchio A, Ladisa G, Latini G: Maternal pulse oximetry perfusion index as a predictor of early adverse respiratory neonatal outcome after elective cesarean delivery. Pediatr Crit Care Med 2008, 9:203-208.

22. Goldman JM, Petterson MT, Kopotic RJ, Barker SJ: Masimo signal extraction pulse oximetry. J Clin Monit Comput 2000, 16:475-483.

23. Dorlas JC, Nijboer JA: Photo-electric plethysmography as a monitoring device in anesthesia. Br J Anaesth 1985, 57:524-530.

24. van Genderen ME, Lima A, Akkerhuis M, Bakker J, van Bommel J: Persistent peripheral and microcirculatory perfusion alterations after out-ofhospital cardiac arrest are associated with poor survival. Crit Care Med 2012, 40:2287-2294.

25. Hasibeder W, Haisjackl M, Sparr H, Klaunzer S, Hörman C, Salak N, Germann R, Stronegger WJ, Hackl JM: Factors influencing transcutaneous oxygen and carbon dioxide measurements in adult intensive care patients. Intensive Care Med 1991, 17:272-275.

26. Reed RL 2nd, Maier RV, Landicho D, Kenny MA, Carrico CJ: Correlation of hemodynamic variables with transcutaneous $\mathrm{PO} 2$ measurements in critically ill adult patients. J Trauma 1985, 25:1045-1053.

27. Jonsson K, Jensen JA, Goodson WH 3rd, West JM, Hunt TK: Assessment of perfusion in postoperative patients using tissue oxygen measurements. Br J Surg 1987, 74:263-267.

28. Waxman K, Annas C, Daughters K, Tominaga GT, Scannell G: A method to determine the adequacy of resuscitation using tissue oxygen monitoring. J Trauma 1994, 36:852-856.

29. Shah JB, Ram DM, Fredrick E, Otto GH, Sheffield PJ: Determination of ideal $\mathrm{PtcO} 2$ measurement time in evaluation of hypoxic wound patients. Undersea Hyperb Med 2008, 35:41-51.

30. Stirban A, Lentrodt S, Nandrean S, Pop A, Tschoepe D, Scherbaum WA: Functional changes in microcirculation during hyperbaric and normobaric oxygen therapy. Undersea Hyperb Med 2009, 36:381-390.

31. Creteur J, Carollo T, Soldati G, Buchele G, De Backer D, Vincent JL: The prognostic value of muscle $\mathrm{StO} 2$ in septic patients. Intensive Care Med 2007, 33:1549-1556.

32. Doerschug KC, Delsing AS, Schmidt GA, Haynes WG: Impairments in microvascular reactivity are related to organ failure in human sepsis. Am J Physiol Heart Circ Physiol 2007, 293:H1065-H1071.

33. Gómez H, Torres A, Polanco P, Kim HK, Zenker S, Puyana JC, Pinsky MR: Use of non-invasive NIRS during a vascular occlusion test to assess dynamic tissue O(2) saturation response. Intensive Care Med 2008, 34:1600-1607.

34. Mesquida J, Espinal C, Gruartmoner G, Masip J, Sabatier C, Baigorri F, Pinsky MR, Artigas A: Prognostic implications of tissue oxygen saturation in human septic shock. Intensive Care Med 2012, 38:592-597. 
35. Lima A, van Bommel J, Jansen TC, Ince C, Bakker J: Low tissue oxygen saturation at the end of early goal-directed therapy is associated with worse outcome in critically ill patients. Crit Care 2009, 13(Suppl 5):S13.

36. Lima A, T Jansen, C Ince, J Bakker: Noninvasive monitoring of peripheral perfusion with physical examination and the peripheral flow index correlates with dynamic near-infrared spectroscopy measurements in patients with septic shock. Critical Care 2008, 12(Suppl 2):P60.

37. Lima A, van Bommel J, Sikorska K, van Genderen M, Klijn E, Lesaffre E, Ince C, Bakker J: The relation of near-infrared spectroscopy with changes in peripheral circulation in critically ill patients. Crit Care Med 2011, 39:1649-1654.

38. Lima A, Bakker $\mathrm{J}$ : The peripheral perfusion index in reactive hyperemia in critically ill patients. Crit Care 2004, 8(Suppl 1):P53.

39. Haisjackl M, Hasibeder W, Klaunzer S, Altenberger H, Koller W: Diminished reactive hyperemia in the skin of critically ill patients. Crit Care Med 1990, 18:813-818.

40. Colin G, Nardi O, Polito A, Aboab J, Maxime V, Clair B, Friedman D, Orlikowski D, Sharshar T, Annane D: Masseter tissue oxygen saturation predicts normal central venous oxygen saturation during early goaldirected therapy and predicts mortality in patients with severe sepsis. Crit Care Med 2012, 40:435-440.

41. Vallée F, Mateo J, Dubreuil G, Poussant T, Tachon G, Ouanounou I, Payen D: Cutaneous ear lobe $\mathrm{PCO} 2$ at $37^{\circ} \mathrm{C}$ to evaluate microperfusion in patients with septic shock. Chest 2010, 138:1062-1070.

\section{doi:10.1186/cc12788}

Cite this article as: He et al:: The peripheral perfusion index and transcutaneous oxygen challenge test are predictive of mortality in septic patients after resuscitation. Critical Care 2013 17:R116.

\section{Submit your next manuscript to BioMed Central and take full advantage of:}

- Convenient online submission

- Thorough peer review

- No space constraints or color figure charges

- Immediate publication on acceptance

- Inclusion in PubMed, CAS, Scopus and Google Scholar

- Research which is freely available for redistribution

Submit your manuscript at www.biomedcentral.com/submit 